\title{
ZJEDNOCZENIE Z BOGIEM W ŻYCIU MORALNYM PRZEZ EUCHARYSTIĘ
}

DOI: http://dx.doi.org/10.12775/TiCz.2021.018

Streszczenie. Życie religijne i moralne chrześcijanina koncentruje się przede wszystkim na Bogu. W świetle Objawienia chrześcijańskiego Jezus Chrystus jest kulminacyjnym punktem zwrócenia się Boga do człowieka, a tym samym człowieka do Boga. Chrześcijanin przyjmujący z wiarą Objawienie wie, że do Boga idzie się tylko przez Chrystusa. Życie moralne jawi się zatem jako naśladowanie życia Chrystusa i udział w jego życiu.

Analizując temat zjednoczenia, nie sposób nie zatrzymać się na Eucharystii jako podstawie życia z Bogiem. Sam Jezus podkreślił niezwykłą rolę Chleba eucharystycznego: „Kto spożywa moje Ciało i Krew moją pije, trwa we Mnie, a ja w Nim” (J 6,56). Chrystus Eucharystyczny przemienia człowieka, upodabniając go do siebie. Chrystus może przemienić człowieka w siebie na tyle, na ile mu człowiek pozwala. Dlatego zadaniem człowieka powinna być nieustanna troska, a niekiedy nawet walka, aby sprawy doczesne, nieuporządkowane życie moralne, nie stanowiły przeszkody na drodze do zjednoczenia z Bogiem.

Celem artykułu jest próba ukazania zjednoczenia z Bogiem jako łaski i zarazem ludzkiego wysiłku poprzez Eucharystię.

Słowa klucze: Bóg; Jezus Chrystus; Eucharystia; zjednoczenie; życie moralne.

Abstract. Union with God in Moral Life through the Eucharist. The religious and moral life of a Christian is primarily concerned with God. In the light of the Christian Revelation, Jesus Christ is the culminating point of God's turning towards man, and consequently also of man turning towards God. A Christian who accepts the Revelation 
with faith knows that one comes to God only through Christ. Moral life, therefore, appears as an imitation of the life of Christ and participation in His life.

In analyzing the theme of union, it is impossible not to take a moment to reflect on the Eucharist as the basis of life with God. Jesus himself emphasized the extraordinary role of the Eucharistic Bread: "Whoever eats my body and drinks my blood remains in me and I in him" (John 6:56). The Eucharistic Christ transforms man by making him conform to Himself. Christ can transform man into Himself as much as man allows Him. Therefore, man's task should be a constant concern, and sometimes even struggle, so that worldly issues and the disordered moral life do not constitute an obstacle on the way to union with God.

The article attempts to present union with God as a grace and, at the same time, a human effort through the Eucharist.

Keywords: God; Jesus Christ; Eucharist; union; moral life.

Życie religijno-moralne chrześcijanina odnosi się przede wszystkim do Boga. W świetle chrześcijańskiego Objawienia punktem kulminacyjnym zwracania się Boga do człowieka, a w rezultacie także człowieka do Boga, jest Jezus Chrystus. Chrześcijanin przyjmujący z wiarą Objawienie wie, że do Boga idzie się nie inaczej, jak tylko przez Chrystusa. Życie moralne jawi się więc jako naśladowanie życia Chrystusa i uczestnictwo w Jego życiu. Bycie uczniem Chrystusa i pójście za Nim jest wypełnieniem tego, co wyraża wewnętrzne zjednoczenie z Chrystusem. Bóg objawia się człowiekowi poprzez swoje Słowo, które nadaje ludzkiemu życiu sens, wskazuje drogę, jak również umożliwia życie w łączności z Nim. Posiada nie tylko moc formacyjną, ale również uświęcającą. Bóg poprzez swoje Słowo najpierw zaprasza człowieka do jedności z sobą, obdarowuje go różnymi darami, a dopiero potem wzywa do wypełnienia określonych zadań. Analizując temat zjednoczenia, nie sposób nie zatrzymać się na Eucharystii jako na podstawie życia z Bogiem ${ }^{1}$. Sam Jezus podkreślał nadzwyczajną rolę Eucharystycznego Chleba: „Kto spożywa moje Ciało i pije moją Krew, trwa we Mnie, a ja w nim" (J 6,56). Chrystus Eucharystyczny swoją obecnością przemienia człowieka, upodobniając go do siebie. Chrystus jednak może na tyle przemienić człowieka w siebie, na ile człowiek mu na to pozwoli. Stąd zadaniem człowieka winna być nieustanna

1 Por. M. Légauut, Introduction à l'intelligence du passé et de l'avenir du Christianiisme, Paris 1970, s. 290 nn. 
troska, czasami wręcz walka o to, by sprawy doczesne, nieuporządkowane życie moralne, nie stanowiły przeszkody w drodze do jedności z Bogiem.

Celem tego artykułu będzie próba przedstawienia zjednoczenia z Bogiem jako łaski, a zarazem wysiłku człowieka, a to wszystko przez Eucharystię.

\section{POTRZEBA ZJEDNOCZENIA Z BOGIEM W ŻYCIU MORALNYM}

Święty Paweł stawia osobę Jezusa Chrystusa w centrum moralności chrześcijańskiej. On bowiem jest celem i kresem dążeń człowieka, a zatem najwyższą zasadą moralnej normy. Według św. Pawła człowiek jest istotą grzeszną, którą Bóg za pośrednictwem Chrystusa pojednał ze sobą (por. 2 Kor 5,18). Jego wezwanie "pojednajcie się z Bogiem” nie jest tylko pobożnym życzeniem, ale naglącym wskazaniem: „W imię Chrystusa” (por. 2 Kor 5,20).

W Piśmie Świętym zawarta jest jeszcze inna, bogatsza nauka o osobistym dążeniu w ślad za Chrystusem. Jest to myśl samego Chrystusa, który podczas ziemskiej wędrówki wzywa poszczególne osoby, by poszły za Nim. Iść śladami Jezusa to być z Nim w osobistym kontakcie. Ojciec Święty Jan Paweł II w encyklice Veritatis splendor przytacza fragment Ewangelii według św. Mateusza o bogatym młodzieńcu, który pyta Jezusa: „Co mam czynić, aby osiągnąć życie wieczne?”. Jezus zachęca swego rozmówcę do zachowania Dekalogu jako prawa moralnego. Młody człowiek, choć z zadowoleniem oświadcza o czystości sumienia odnośnie zachowywania prawa, to nie czuje się usatysfakcjonowany odpowiedzią Jezusa. Nie tyle „chodzi mu o to, jakich zasad należy przestrzegać, ale jak osiągnąć pełny sens życia”2. Kiedy pyta o więcej: „czego mi jeszcze brakuje”, Jezus patrzy na niego z miłością i daje mu odpowiedź: „Jeśli chcesz być doskonały, idź sprzedaj wszystko, co posiadasz i rozdaj ubogim..." (Mt 19,21) ${ }^{3}$. Odpowiedź na Boże wezwanie zakłada u młodego człowieka wolność i radykalność. Młodzieniec, który zachowywał dotąd wszystkie przykazania,

2 Jan Paweł II, Encyklika Veritatis splendor, Poznań 1993, nr 7, (dalej VS).

3 Por. Jan Paweł II, List Apostolski do młodych całego świata z okazji Międzynarodowego Roku Młodzieży, Watykan 1985, nr 8. 
nie jest zdolny pójść dalej ${ }^{4}$. Pójście za Jezusem wymaga bowiem od człowieka całkowitego wyrzeczenia się samego siebie, a także przyjęcia prawdy o ludzkiej słabości i ograniczoności. Człowiek nie potrafi o własnych siłach pójść za Jezusem, „staje się zdolny do takiej miłości jedynie mocą udzielonego mu daru"5. Zaproszenie skierowane do młodzieńca, jak również do każdego z nas, jest wezwaniem do zażyłości z Bogiem. Dopiero przeżyte spotkanie z Bogiem staje się kryterium dla interpretacji sensu całego życia. Szczerość przylgnięcia do Boga zależy w pierwszej kolejności od sumienia osoby, ale przede wszystkim od jej postawy moralnej6.

Na Soborze Watykańskim II, w Konstytucji dogmatycznej o Kościele Lumen Gentium podkreślono, iż uczestnictwo w życiu Jezusa (świętość) jest powołaniem nie tylko osób duchownych, ale wszystkich bez wyjątku. Każdy jest wezwany do doskonałej świętości ${ }^{7}$, do doskonałej miłości $^{8}$ i do pełni chrześcijańskiego życia ${ }^{9}$. Wezwanie to odnosi się do każdego, zgodnie $\mathrm{z}$ jego stanowiskiem i pozycją ${ }^{10}$, zgodnie $\mathrm{z}$ jego obowiązkami i zdolnościami, a także zgodnie z siłami, które otrzymał w darze od Chrystusa $^{11}$. Powołanie chrześcijańskie jest nade wszystko darem i łaską, ale zarazem wezwaniem i nakazem, aby żyć jako człowiek odkupiony, a nie jako związany ze światem, który popadł we władzę grzechu oraz aby żyć jako człowiek powołany do zbawienia (a nie jako pozostawiony zatraceniu) ${ }^{12}$. W każdej sytuacji On okazuje swą miłość, konfrontuje człowieka z samym sobą i wzywa ku sobie. Święty Alfons Liguori uważa życie moralne za „nieustanną wędrówkę", której towarzyszy sam Bóg. Zrealizuje się ono w pełni tylko pod warunkiem, że człowiek pozwoli łasce Bożej, aby przemieniała go w Chrystusa ${ }^{13}$. „Już nie ja żyję, ale żyje we mnie Chrystus" (Gal 2,20) powie św. Paweł w Liście do Galatów.

4 Por. VS, nr 17.

5 Tamże, nr 22.

6 Por. S. Bastinel, Modlitwa i moralność, Kraków 1989, s. 28-29.

7 Por. Sobór Watykański II, Konstytucja dogmatyczna o Kościele Lumen Gentium, w: Sobór Watykański II, Konstytucje. Dekrety. Deklaracje, Poznań 2002, s. 113-114, nr 11

8 Por. Tamże, nr 39.

9 Por. Tamże, nr 40.

10 Por. tamże, nr 39.

11 Por. tamże, nr 40.

12 Por. A.M. Liguori, Umiłowanie Chrystusa w życiu codziennym, Kraków, s. 35.

13 Por. tamże, s. 33-34. 
Łaska Ducha Chrystusowego sprawia przede wszystkim to, że człowiek współuczestniczy w życiu i miłości samego Chrystusa, w wyniku czego może on kochać podobnie jak kocha Chrystus. Miłość jest tą cnotą, która jednoczy z Nim: „Kto trwa w miłości trwa w Bogu, a Bóg trwa w nim” $(\mathrm{J} 4,16)$. Dla św. Augustyna miłość jest kluczem, który pozwala wejść w najgłębsze życie Boga oraz w Jego tajemnicę ${ }^{14}$. Prawdziwa miłość Boga polega przede wszystkim na zjednoczeniu z Jego wolą, a to zakłada całkowitą ufność i uległość człowieka. „Zgodność z wolą Bożą jest największym skarbem chrześcijanina oraz lekarstwem na wszelkie zło, bo zawiera w sobie wyrzeczenie się samego siebie, jedność z Bogiem oraz wszystkie cnoty"15.

Miłość, jakiej domaga się Jezus, jest odpowiedzią na uprzednią miłość Boga, która nie zna granic. Natomiast w kontekście zesłania Ducha Świętego miłość jest przedstawiona nie tylko jako wyłączny wysiłek moralny człowieka, ale jako wewnętrzna przemiana, która jest owocem łaski, a której dopełnieniem są uczynki miłości. Według św. Pawła prawdziwa miłość wyraża się w darze z samego siebie (por. 2 Kor 5,14-15). Taka miłość, która zupełnie opiera się na Bogu „agape”, nie ma nic wspólnego z szukaniem siebie. Święty Paweł ukazuje ją jako najwyższą normę działania (por. 1 Kor 13).

Dla św. Jana miłość jest kryterium prawdziwości bycia chrześcijaninem. Miłość jest potwierdzeniem jedności z Bogiem i wyzwoleniem z grzechu (por. $1 \mathrm{~J} 2,5,10-11$ ). Dlatego miłość może stanowić autentyczne kryterium bycia uczniem Jezusa i zjednoczenia z Nim: „Po tym wszyscy poznają, żeście uczniami moimi, jeśli będziecie się wzajemnie miłowali” (J 13,35). W świetle nauczania biblijnego miłość jest podstawą wszelkich postaw moralnych.

Życie chrześcijańskie jest życiem z Chrystusem i w Chrystusie, stąd też moralność chrześcijańska jest moralnością wiary. Wiara rozumiana jako powierzenie siebie Bogu obejmuje całego człowieka i wszystkie wymiary jego egzystencji. Człowiek przyjmując Boże objawienie, poprzez wiarę wchodzi we wspólnotę z Bogiem. Można by powiedzieć, że zarówno wiara, jak i miłość zbiegają się w jedno. Bez wiary nie byłoby miłości

14 Por. J. Garcia, Święty Augustyn, Kraków 1998, s. 51.

15 A.M. Liguori, Umiłowanie Chrystusa w życiu codziennym, s. 161-162. 
prawdziwie chrześcijańskiej, a bez miłości nie byłoby pełnej wiary. Miłość chrześcijańska niejako wypływa $\mathrm{z}$ wiary i jest jej uzewnętrznieniem ${ }^{16}$.

Człowiek ma obowiązek przyjęcia wiary, trwania w niej i wzrastania na miarę otrzymanej łaski. Do wzrastania w wierze nawołuje sam Jezus Chrystus. Upomina bowiem swoich uczniów, że mają za mało wiary (por. Mt 8,25). Żywa wiara i prawdziwa miłość wymagają prowadzenia z Bogiem stałego dialogu dla doprowadzenia do zjednoczenia z Nim w życiu moralnym.

\section{PODSTAWOWE ŹRÓDŁA ZJEDNOCZENIA Z BOGIEM}

Chrystus przed swoją męką na Kalwarii powiedział do swoich uczniów: „Nie nazywam was sługami, bo sługa nie wie co czyni pan jego, ale nazwałem was przyjaciółmi, albowiem oznajmiłem wam wszystko, co usłyszałem od Ojca mojego" (J 15,15). Chrystus nazywając swoich uczniów przyjaciółmi pragnie dzielić z nimi swoje życie, silnie zjednoczone z Ojcem: „Ja i Ojciec jedno jesteśmy”. Relacja Jezusa do Ojca zakorzeniona jest w osobowej miłości, którą jest Duch Święty. Jemu papież Leon XIII przypisuje „tę więź miłości, jaka bardzo ściśle łączy duszę z Bogiem, ściślej niż przyjaciela z najlepszym i ukochanym przyjacielem" ${ }^{17}$.

Rozpatrując temat zjednoczenia z Bogiem, warto zatrzymać się na dwóch ważnych tekstach Pisma Świętego mówiących o istocie ludzkiego życia: „Nie samym chlebem żyje człowiek, lecz każdym słowem, które pochodzi z ust Bożych” (Mt 4,4) oraz na słowach Jezusa: „Kto spożywa moje Ciało i Krew moją pije, trwa we Mnie, a Ja w nim” (J 6,56). słowo Boże, modlitwa, ofiara eucharystyczna, to podstawowe źródła jedności z Bogiem.

Święty Hieronim uważa słowo Boże jako pokarm podobny do pokarmu eucharystycznego, który jest źródłem życia wewnętrznego, zaś nieznajomość Pisma św. traktuje jako nieznajomość Chrystusa ${ }^{18}$.

Sobór Watykański II w Konstytucji Dogmatycznej o Objawieniu Bożym zatrzymując się nad Pismem św. stwierdza: „W Księgach świętych

${ }^{16}$ Por. J. Nagórny, Moralność chrześcijańska, w: Katechizm Kościoła katolickiego wprowadzenie, red. M. Rusecki, E. Pudełko, Lublin 1995, s. 200.

17 A. Marchetti, Zarys teologii życia duchowego, Kraków 1996, s. 79.

18 Por. J. Kudasiewicz, Odkrywanie Ducha Świętego, Kielce 1998, s. 28. 
Ojciec, który jest w niebie, spotyka się miłościwie ze swymi dziećmi i pro-

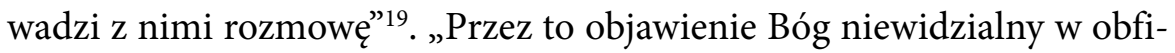
tości swej miłości zwraca się do ludzi jako przyjaciół i obcuje z nimi, aby ich zaprosić do wspólnoty z sobą i przyjąć ich do niej”20.

W Starym Testamencie Bóg poprzez swoje słowo powoływał ludzi i zlecał im zadania do wykonania. Pierwszą rzeczą, która zwraca uwagę $\mathrm{u}$ rozmawiających z Bogiem, jest ich wielka ufność i niewiarygodna odwaga, z jaką mówią z Bogiem. O Mojżeszu Biblia mówi, że „Pan rozmawiał z nim twarzą w twarz, jak się rozmawia z przyjacielem” (Wj 33,11) ${ }^{21}$. Poprzez przymierze Bóg wiąże się z nim, by prowadzić go do ziemi obiecanej, którą ostatecznie będzie sam Bóg i zjednoczenie z Nim² ${ }^{22}$. Słowo Boga nie tylko jednoczy, ale pośredniczy w spotkaniu Mojżesza z ludem.

Podobną funkcję pełniło słowo u proroków. Każdy z nich jest wezwany przez Pana po to, by wskazywał drogę do nieba jakże często opornemu ludowi. Słowo, którym posługuje się Bóg przez swych mediatorów, jest często trudne i niezrozumiałe dla ludzi, którzy są zamknięci na jego działanie, stąd budzi sprzeciw i niechęć. Jeremiasz z bólem mówi, że słowo Pańskie stało się dla niego zniewagą i pośmiewiskiem (por. Jr 20,8), ale moc Boża jest silniejsza - pomimo wysiłku nie potrafi go w sobie stłumić (por. Jr 20,9). Izajasz w podsumowaniu swej księgi umieścił piękny kantyk na cześć słowa Bożego, porównując je do śniegu i deszczu, które przynoszą ziemi życie (por. Iz 55,10-11). Według proroka między niebem a ziemią istnieje pewna łączność. Bóg poprzez swoje słowo staje się bliski człowiekowi, mimo że istnieje między nimi wielki dystans. Słowo Boże wywołuje to, co Bóg zamierza przez nie uczynić, ale poprzez pośrednictwo słuchania i przyjęcia z wiarą zbawczego orędzia przez ludzi. Daje ono początek pewnemu dynamizmowi, od którego pochodzi owoc. Słowo nie tylko przekazuje informacje, ale sprawia to, co zapowiada, nie wraca ono do Boga puste i bezowocne ${ }^{23}$.

19 Sobór Watykański II, Konstytucja dogmatyczna o Objawieniu Bożym Dei Verbum, w: Sobór Watykański II, Konstytucje. Dekrety. Deklaracje, nr 21.

${ }^{20}$ Tamże, nr 2.

${ }^{21}$ Katechizm Kościoła Katolickiego, Poznań 2002, nr 2576.

22 Por. J. Loew, Modlitwa w szkole wielkich przyjaciół Boga, Warszawa 1977, s. 43.

23 Por. J. Kudasiewicz, Odkrywanie Ducha Świętego, s. 39. 
W Nowym Testamencie słowo Jezusa podobnie jak słowo Jahwe ma moc jednoczenia wierzących z Nim. Ci, którzy go słuchają i zachowują je w życiu tworzą z Jezusem rodzinę duchową: „Moją Matką i moimi braćmi są ci, którzy słuchają słowa Bożego i wypełniają je” (Łk 8,21).

Słowo Boże angażuje całe życie i przemienia je od wewnątrz, nadaje ludzkiemu życiu sens, wskazuje drogę wprowadzając człowieka w komunię z Jezusem ${ }^{24}$. Przez czytanie słowa Bożego człowiek wchodzi w kontakt z Duchem Świętym, dzięki któremu słowo Boże nie jest słowem przeszłości, ale ciągle żywym i aktualnym. Pod jego kierunkiem człowiek przechodzi poprzez literę aż do głębi misterium. Ojcowie Kościoła ogromną rolę przypisywali dyspozycjom moralnym takim jak: czystość serca, wiara, pokora, wyciszenie, które sprawiały, że chrześcijanin stawał się zdolny do przyjęcia słowa Bożego. Podkreślali również wartość „lectio divina”, która nazywana jest „czytaniem ewangelii w sposób modlitewny”. „W lectio nie tylko słuchamy i rozważamy słowa Jezusa, ale uważamy je przede wszystkim za przedmiot modlitwy i przyjęcia tegoż słowa, które zachowane w sercach wiernych, prowadzi ich do stałego nawracania się oraz do harmonijnego apostolskiego świadectwa" 25 .

Słuchanie słowa Bożego, rozważanie go, a następnie wprowadzanie go w życie odgrywało wielką rolę zarówno w życiu całych wspólnot, jak i poszczególnych osób, głównie tych, których Kościół czci dziś jako świętych. Jako przykład można wziąć rolę słowa w życiu św. Teresy z Lisieux. W Piśmie Świętym znajdowała „pokarm mocny i czysty”. Pomocą dla niej była nade wszystko Ewangelia: „Ona zaspokaja wszystkie potrzeby mojej biednej duszy, odkrywam w niej coraz to nowe światła oraz jej sens ukryty i mistyczny" ${ }^{26}$. Święta Teresa wyraża pragnienie, by głosić Ewangelię całemu światu, dla niej bowiem Ewangelia jest Słowem Bożym, w którym Chrystus przekazuje swą naukę: to, co jest najistotniejsze dla życia duchowego. ${ }^{27}$.

24 Por. tamże, s. 43.

${ }^{25}$ Jezus Chrystus, jedyny Zbawiciel świata, wczoraj, dziś i na wieki, Oficjalny dokument Papieskiego Komitetu Obchodów Wielkiego Jubileuszu Roku 2000, Katowice 1996, s. 82 .

26 T.M. Dąbek, Biblia w pismach św. Teresy od Dzieciątka Jezus, w: Mała droga zupetnie nowa św. Teresy od Dzieciątka Jezus - materiały z sympozjum, Kraków 1992, s. 68.

27 Por. tamże, s. 66. 
Słuchanie słowa Bożego, Jego znajomość i życie Nim prowadzi $\mathrm{w}$ prostej linii do następnego fundamentalnego elementu zjednoczenia z Bogiem, jakim jest modlitwa. Każda forma modlitwy chrześcijańskiej prowadzi do ściślejszego zjednoczenia z Bogiem, a w miarę jak modlitwa zostaje pogłębiona spotkanie staje się coraz bardziej zażyłe, staje się prawdziwą łącznością z Ojcem, Jego Synem Jezusem Chrystusem w Duchu Świętym (por. $1 \mathrm{~J} 1,3$ ).

Modlitwą, która najbardziej jednoczy człowieka z Bogiem jest Eucharystia. Człowiek spożywając chleb eucharystyczny jednoczy swoje serce z Sercem Jezusa „Ten zaś kto się łączy z Panem, jest z Nim jednym Duchem" (1 Kor 6,17). Z Eucharystii wyrasta także braterska łączność z tymi, którzy podobnie jak my uczestniczą w uczcie Chrystusa (por. 1Kor 6,17), a pełne zjednoczenie z Bogiem szczególnie w życiu moralnym, jak również całe modlitewne i sakramentalne życie Kościoła przebiega w perspektywie trynitarnej w Duchu przez Chrystusa do Ojca ${ }^{28}$.

\section{ZJEDNOCZENIE Z BOGIEM PRZEZ EUCHARYSTIĘ}

Najważniejszym i najbardziej znaczącym dla życia moralnego źródłem zjednoczenia chrześcijanina $z$ Bogiem jest Eucharystia. Jest ona również „źródłem życia chrześcijańskiego, ponieważ z uczestnictwa w niej człowiek czerpie inspirację i moc, by żyć jak prawdziwy chrześcijanin"29. $\mathrm{W}$ tym sakramencie wierni łączą ofiarę Chrystusa $\mathrm{z}$ własnymi ofiarami, które zostają uświęcone i wyniesione ku Bogu w kulcie wprowadzającym wiernych w zażyłość z Bogiem ${ }^{30}$. „Kościół troszczy się o to, aby chrześcijanie [...] ofiarując niepokalaną Hostię [...] uczyli się samych siebie składać w ofierze i za pośrednictwem Chrystusa z każdym dniem doskonalili się w zjednoczeniu z Bogiem" ${ }^{31}$. Najświętszy Sakrament w pełnych swych wymiarach jest równocześnie - wyjaśnia Jan Paweł II - „sakramentem -

28 Por. Jan Paweł II, Wierzę w Boga Ojca Stworzyciela, Città del Vaticano, s. 169-173.

${ }_{29}$ Tenże, Wierzę w Kościół jeden, święty, powszechny i apostolski, Città del Vaticano 1996, s. 130.

30 Por. J.M. Aubert, Compendio della morale cattolica, Milano 1989, s. 235-238.

31 Sobór Watykański II, Konstytucja o liturgii świętej Sacrosanctum Concilium, w: Sobór Watykański II, Konstytucje. Dekrety. Deklaracje, Poznań 2002, nr 48. 
ofiarą, sakramentem - komunią i sakramentem - obecnością"32. Eucharystia jako sakrament - komunia wyraża się w zjednoczeniu człowieka z Bogiem, dzieje się to przez pomnożenie w wiernych łaski uświęcającej. Komunia na wzór pokarmu naturalnego regeneruje siły duchowe, sprawia ich wzrost, a także pobudza do głębszej i żywszej miłości Boga i bliźniego $^{33}$. Przyjąć Komunię świętą, to przyjąć oddającą się miłość Bożą, która dla dobra człowieka potrafi przekształcić w siebie. Święty Jan Chryzostom powie, iż Chrystus w Komunii jednoczy się z nami tak, że jego Ciało i nasze staje się jakby jednym ciałem. Święty Cyryl zaś porównuje to zjednoczenie z Jezusem do dwóch kawałków wosku stapiających się ze sobą ${ }^{34}$.

Wielu teologów, a szczególnie znawców życia duchowego stwierdza, iż kto spożywa chleb eucharystyczny, ten jednoczy swoje serce z Bożym sercem, by działać w jedności. Im ściślej człowiek jest zjednoczony, tym bardziej z Nim żyje. Eucharystia jest nie tylko pokarmem duszy, ale przynosi również korzyści ciału, jest źródłem przemiany w Chrystusa ${ }^{35}$, jest Obecnością Chrystusa. Sam Jezus porównuje swą obecność do obecności oblubieńca przy oblubienicy (por. Mt 9,15), a kiedy żegna się z uczniami zaznacza: „A oto Ja jestem z wami przez wszystkie dni, aż do skończenia świata” (Mt 28,20). Dlatego Sobór Trydencki mocno podkreślił, „że Jezus Chrystus jako Bóg i człowiek jest prawdziwie, rzeczywiście i substancjalnie obecny w Eucharystii. Ta Jego obecność nie ogranicza się tylko do liturgii Mszy św., lecz także trwa poza nią”, szczególnie w życiu moralnym ${ }^{36}$.

Święty Augustyn w swoich pismach Eucharystię określa jako: „Wielki Sakrament, Sakrament Miłosierdzia, Znak Jedności, Węzeł Miłości”37. Augustyn podkreśla, że ten węzeł miłości łączy z Chrystusem ludzi o dobrym sercu, o dobrych obyczajach, posiadających wierną miłość do Chrystusa. Ci ludzie spożywając Eucharystię i pijąc Krew pańską, spożywają Boże miłosierdzie. Źli spożywając to samo Ciało i Krew pańską, sprowa-

32 Jan Paweł II, Encyklika Redemptor hominis, Watykan 1979 nr 20 (dalej RH).

33 Por. M. Kołodziejczyk, Eucharystia a Kościót, w: Eucharystia źródłem życia, red. S. Grzybek, Kraków 1987, s. 112.

34 Por. J.S. Płatek, Sam na sam z Bogiem, Częstochowa 1997, s. 392.

35 Por. tamże, s. 393.

36 Sobór Trydencki, Sesja 13, kan. 1, w: Breviarium Fidei, VII, 298, Poznań 1998, s. 404 .

37 Cyt. za: H. Wójtowicz, Nauka św. Augustyna o Wielkim Sakramencie miłości, w: Eucharystia - miłość i dziękczynienie, red. W. Słomka, A.J. Nowak, Lublin 1992, s. 35. 
dzają na siebie sąd. Zgodnie z wypowiedziami św. Augustyna Eucharystia jest również węzłem niepodzielnej miłości i węzłem pokoju między chrześcijanami. Jest znakiem najgłębszej rzeczywistości Kościoła, ponieważ odkrywa misterium Ciała Chrystusowego. Wszyscy chrześcijanie zjednoczeni z Chrystusem tworzą z Nim jedno Ciało ${ }^{38}$.

Mając na uwadze głęboki i życiodajny wpływ Eucharystii na Kościół, Jan Paweł II porównał ją do „serca Kościoła, sekretu jego żywotności ${ }^{39}$, ponieważ w niej „zawiera się całe dobro duchowe Kościoła, a mianowicie sam Jezus Chrystus, nasza Pascha i chleb żywy, który przez Ciało swoje ożywione i ożywiające Duchem Świętym daje życie ludziom, zapraszając ich i doprowadzając w ten sposób do ofiarowania razem z Nim samych siebie" ${ }^{\prime 0}$. Zarówno życie całego Kościoła, jak i każdego chrześcijanina osiąga swój szczyt i pełnię w Eucharystii. W niej bowiem nie tylko wspomina się krzyżową śmierć Chrystusa, ale także odnawiana jest Jego ofiara składana Ojcu dla zbawienia świata. Chrystus, ustanawiając Eucharystię w przededniu swojej śmierci, pragnął dać Kościołowi pokarm miłości, który pozwoliłby mu żyć życiem Chrystusa zmartwychwstałego. To życie wyróżnia się mocą i bogactwem. Ten, kto przystępuje do Komunii Świętej, otrzymuje duchową siłę, potrzebną do tego, by stawiać czoła wszystkim trudnościom i próbom, dochowując wierności zobowiązaniom chrześcijanina. Komunia Święta daje poza tym siłę moralną niezbędną do tego, by „przejść ponad przyczynami podziałów” po to, by wybaczyć doznane krzywdy, by dokonać ponownego wysiłku w duchu pojednania ${ }^{41}$. Wewnętrzna wolność jest jednym $\mathrm{z}$ warunków przyjęcia miłości Chrystusa. Warto jeszcze zaznaczyć, iż Eucharystia stawia pewne szczególne wymagania czystości serca, które zresztą Jezus wyraźnie podkreślił podczas Ostatniej Wieczerzy. By móc przyjąć łaskę eucharystycznego pokarmu, wymagane są określone dyspozycje serca natomiast, ich brak grozi wielkim „niebezpieczeństwem przekształcenia posiłku w zdradę" (por. 1 Kor 11,27-29). Każdy przed przystąpieniem do Komunii św.

38 Por. tamże, s. 40-41.

39 Jan Paweł II, Nauczanie społeczne 1981, t. 4, Warszawa 1984, s. 156.

40 Sobór Watykański II, Dekret o posłudze i życiu prezbiterów Presbyterorum ordinis, w: Sobór Watykański II, Konstytucje. Dekrety. Deklaracje, Poznań 2002, nr 5.

${ }^{41}$ Por. Jan Paweł II, Audiencja generalna, Watykan 8 VI 1983, w: Eucharystia w nauczaniu Jana Pawła II, Antologia wypowiedzi, Kraków, s. 105-109. 
jest wezwany do tego, by w sumieniu ocenił, czy może godnie przyjąć Jezusa do serca ${ }^{42}$. Uczestnictwo w Eucharystii wymaga ciągłego trudu nawracania się, prowadzenia coraz to doskonalszego życia, bez niego samo uczestnictwo w Eucharystii zostałoby pozbawione „pełnej skuteczności zbawczej”"33. Dlatego każdy człowiek gromadzący się przy ołtarzu w celu sprawowania Eucharystii ma szczególne zadanie starać się być znakiem jedności z Chrystusem i Kościołem. Dyspozycja taka wymaga nieustannej troski i czuwania nad jakością życia moralnego ${ }^{44}$.

\section{ZAKOŃCZENIE}

Życie moralne chrześcijanina jest życiem w jedności z Chrystusem we wspólnocie Kościoła. Zakłada ono fakt uwierzenia w Chrystusa i dostrzeżenia w Nim punktu odniesienia wszelkich relacji i wartości moralnych. Owa łączność z Chrystusem ma charakter przekraczający wymiar jedynie moralny. Ma ona bowiem wymiar mistyczny - życie człowieka jest łącznością z Osobą i misją samego Jezusa. Ten głęboki synowski związek człowieka z Bogiem jest dziełem Ducha Świętego. On jest sprawcą miłości jednoczącej ludzi z Bogiem i między sobą, On uczy wszelkiej prawdy, daje życie i otwiera przystęp do Ojca. Rolą człowieka jest pozwolić Duchowi dotrzeć do siebie otwierając Mu swoje serce. Duch Święty, tak jak niegdyś w Chrystusie jest głównym sprawcą życia modlitwy. To On wzbudza potrzebę i wolę Chrystusowego nakazu: „Czuwajcie i módlcie się" (Mt 29,41), oświeca każdego człowieka, kieruje jego postępowaniem i wskazuje właściwą drogę życia.

Człowiek, by dojść do zjednoczenia z Bogiem winien najpierw starać się o urzeczywistnienie woli Bożej, która ujawnia się w sposób ogólny dla wszystkich przez Pismo Święte i przykazania. Z biegiem czasu, nie może jednak zatrzymywać się tylko na przestrzeganiu generalnych zasad, ale musi zrozumieć, czego Bóg od niego wymaga. Jest rzeczą oczywistą, że

42 Por. Jan Paweł II, Audiencja generalna, Watykan 15 VI 1983, w: tamże, s. 111-112.

$43 \mathrm{RH}, \mathrm{nr} 20$.

${ }^{44}$ S. Vincenzo de'Paoli, Conferenze spirituali alle Figlie della Carità, Roma 1980, s. $266-270$. 
Bóg kocha wszystkich jednakową miłością, lecz zarazem dla każdego przygotował inną drogę, którą człowiek winien przez modlitwę odkrywać.

Spotkanie między Bogiem a człowiekiem przebiega pod znakiem miłości, która ma swoje urzeczywistnienie w osobie Jezusa Chrystusa głównie w Jego darze dla człowieka - mianowicie w Eucharystii. To z Eucharystii wypływa właściwy stosunek człowieka do Boga i do ludzi. Miłość do Eucharystii uczy także właściwej skali wartości i uznawania na pierwszym miejscu tego, co Bóg chce od człowieka. Eucharystia wzywa człowieka do lepszego korzystania z owoców męki, śmierci i zmartwychwstania Jezusa dla własnego dobra i ku pożytkowi bliźnich. Obecny w Eucharystii Jezus wyjaśnia, dlaczego pokarm Jego Ciała jest niezbędny w drodze do Ojca: „Ja jestem chlebem żywym, który zstąpił z nieba. Jeśli kto spożywa ten chleb, będzie żył na wieki” (J 6,51). Przystępując do Stołu Eucharystii, człowiek otrzymuje duchową siłę, potrzebną do tego, by stawić czoło różnym trudnościom, problemom, dochowując wierności zobowiązaniom płynącym z zasad moralnego życia.

\section{BIBLIOGRAFIA}

\section{Nauczanie Magisterium Kościoła}

Jan Paweł II, Encyklika Redemptor hominis, Watykan 1979.

Jan Paweł II, Encyklika Veritatis splendor, Poznań 1993.

Jan Paweł II, Audiencja generalna, Watykan 8 VI 1983, w: Eucharystia w nauczaniu Jana Pawła II, Antologia wypowiedzi, Kraków 1987, s. 105-109.

Jan Paweł II, List Apostolski do młodych całego świata z okazji Międzynarodowego Roku Młodzieży, Watykan 1985.

Jan Paweł II, Nauczanie społeczne 1981, t. 4, Warszawa 1984.

Jan Paweł II, Wierzę w Boga Ojca Stworzyciela, Città del Vaticano 1987.

Jan Paweł II, Wierzę w Kościół jeden, święty, powszechny i apostolski, Città del Vaticano 1996.

Jezus Chrystus, jedyny Zbawiciel świata, wczoraj, dziś i na wieki, Oficjalny dokument Papieskiego Komitetu Obchodów Wielkiego Jubileuszu Roku 2000, Katowice 1996.

Katechizm Kościoła Katolickiego, Poznań 2002.

Sobór Trydencki, Sesja 13, kan. 1, w: Breviarium Fidei, VII, 298, Poznań 1998.

Sobór Watykański II, Dekret o postudze i życiu prezbiterów Presbyterorum ordinis, w: Sobór Watykański II, Konstytucje. Dekrety. Deklaracje, Poznań, s. 474-508.

Sobór Watykański II, Konstytucja dogmatyczna o Kościele Lumen Gentium, w: Sobór Watykański II, Konstytucje. Dekrety. Deklaracje, Poznań 2002, s. 97-166. 
Sobór Watykański II, Konstytucja dogmatyczna o Objawieniu Bożym Dei Verbum, w: Sobór Watykański II, Konstytucje. Dekrety. Deklaracje, Poznań 2002, s. 339-363.

Sobór Watykański II, Konstytucja o liturgii świętej Sacrosanctum Concilium, w: Sobór Watykański II, Konstytucje. Dekrety. Deklaracje, Poznań 2002, s. 23-78.

\section{Literatura}

Aubert J. M., Compendio della morale cattolica, Milano 1989.

Bastinel S., Modlitwa i moralność, Kraków 1989.

Dąbek T.M., Biblia w pismach św. Teresy od Dzieciątka Jezus, w: Mała droga zupełnie nowa św. Teresy od Dzieciątka Jezus - materiały z sympozjum, Kraków 1992.

Garcia J., Święty Augustyn, Kraków 1998.

Kołodziejczyk M., Eucharystia a Kościót, w: Eucharystia źródłem życia, red S. Grzybek, Kraków 1987.

Kudasiewicz J., Odkrywanie Ducha Świętego, Kielce 1998.

Légauut M., Introduction à l'intelligence du passé et de l'avenir du Christianiisme, Paris 1970.

Liguori A.M., Umiłowanie Chrystusa w życiu codziennym, Kraków.

Loew J., Modlitwa w szkole wielkich przyjaciół Boga, Warszawa 1977.

Marchetti A., Zarys teologii życia duchowego, Kraków 1996.

Nagórny J., Moralność chrześcijańska, w: Katechizm Kościoła katolickiego - wprowadzenie, red. M. Rusecki, E. Pudełko, Lublin 1995.

Płatek J. S, Sam na sam z Bogiem, Częstochowa 1997.

Vincenzo de'Paoli, Conferenze spirituali alle Figlie della Carità, Roma 1980.

Wójtowicz H., Nauka św. Augustyna o Wielkim Sakramencie miłości, w: Eucharystia miłość i dziękczynienie, red. W. Słomka, A.J. Nowak, Lublin 1992. 